\title{
Clô: uma personagem da sociedade de consumo
}

Maria Aparecida Baccega

Docente do Programa de Pós-graduação de Comunicação e Práticas de Consumo - stricto sensu - ESPM/SP.

E-mail: mabga@espm.br

Rosilene Moraes Alves Marcelino

Mestranda do Programa de Pós-Graduação de Comunicaşão e Práticas de Consumo - stricto sensu - ESPM/SP.

E-mail: rosilene.marcelino@hotmail.com

Resumo: Neste trabalho procuramos mostrar, sem laço de subordinação, a comunicação e o consumo como aspectos constituídos e constituintes na/da cultura. Para isso, trazemos à reflexão alguns capítulos da telenovela Passione, focalizando nossa atenção na personagem Clotilde Iolanda Souza e Silva (Clô), para mostrar o papel do consumo na atualidade como chave de leitura da sociedade contemporânea.

Palavras-chave: Comunicação e práticas de consumo, telenovela, recepção, mediação, educação.
Abstract: In this work, we show, without subordination ties, communication and consumption as aspects that constitute and are constituted by culture. For that, we bring to reflection some chapters of the telenovela Passione, calling attention to the character Clotilde lolanda Souza e Silva (Clô), to show the role of consumption in present days as the key to interpret the contemporary society.

Keywords: communication and consumptions practices, consumption, telenovela, reception, mediation, education.

Neste trabalho, como nos propõem Martín-Barbero e Rey ${ }^{1}$, reconhecemos a televisão como um espaço de trânsito de dinâmicas sociais e como propulsora de transformações, capaz de moldar e deformar a todo instante o cotidiano e o popular, dialeticamente. Não escapamos à mídia, como nos lembra Silverstone $^{2}$ e, por este motivo, devemos buscar entendê-la como parte significativa da capacidade de se compreender o mundo, como um processo eternamente social em curso e, ao mesmo tempo, uma coisa feita, que perpassa a vida social e a cultura contemporânea.

Para Baccega, o aparato midiático deve ser compreendido na atualidade como uma agência de socialização, tal como a escola e a família (agências tradicionais), instaurando-se um "embate permanente na disputa pela hegemonia na formação dos sujeitos" ${ }^{\text {" }} \mathrm{e}$, consequentemente, nos sentidos sociais. A autora chama-nos a atenção para o fato de que, neste embate entre agências de socialização, a questão do consumo emerge como formadora de identidades. Rocha corrobora com esta perspectiva ao afirmar que o ato de consumir "é

Recebido: 30.06.2011

Aprovado: 19.07.2011

1. MARTÍN-BARBERO, J. REY, G. Os exercícios do ver: hegemonia audiovisual e ficção televisiva. São Paulo, 2004. p. 24-26.

2. SILVERSTONE, Roger. Por que estudar a mídia? São Paulo: Loyola, 1999. p. 16-17.

3. BACCEGA, Maria A. Comunicação/educação: relações com o consumo. Importância para a constituição da cidadania. Comunicação, mídia e consumo, ano 7, v. $7, n$. 19, p. 53, 2011. 
4. ROCHA, Rose de Melo. Comunicação e consumo: por uma leitura política dos modos de consumir. In: BACCEGA, Maria A. (org.). Comunicação e culturas do consumo São Paulo: Atlas, 2008. p. 122-123.

5. ANDRADE, Danubia. De conto de fadas a conto de fatos: a telenovela e suas relações com a identidade. Lumina, v. 3 , n. 2, p. 8, dez. 2009. Disponível em: <http://www. ppgcomufjf.bem-vindo. net/lumina/index.php? journal $=$ edicao \& page = article\&op=view\& path[] $=101 \&$ path []$=153>$. Aces so em: set. 2010

6. FALCÃO, Maria do C. O conhecimento da vida cotidiana: base necessária à prática social. In: NETTO José Paulo; FALCÃO, Maria do Carmo. Cotidiano: conhecimento e crítica. São Paulo: Cortez, 1989. p. 13-19.

7. LOPES, Maria I. V. de. Telenovela como recurso comunicativo. Matrizes, $v$ 3, n. 1, 2009. Disponível em: <http://www.matrizes.usp.br/ojs/index.php/ matrizes/article/viewFile/79/pdf_67>. Acesso em: 15 jul. 2011.

8. BACCEGA, Maria A., SANCHEZ, Fabio. Novela é cultura. Veja, 24 jan. 1996.

9. BACCEGA, op. cit., 2011. p. 5.

10. ROCHA, Everardo Os bens como cultura: Mary Douglas e a antropologia (apresentação) In: DOUGLAS, Mary ISHERWOOD. O mundo dos bens. Para uma antropologia do consumo. Rio de Janeiro: UFRJ, 2004. p. 9 mais do que mero exercício de gostos, caprichos ou compras irrefletidas, mas todo um conjunto de processos e fenômenos socioculturais complexos"; ; além disso, prossegue o autor, o consumo está inserido em toda a rede midiática. Neste contexto, a telenovela emerge como um produto cultural midiático que estabelece "um paralelismo entre as rotinas das personagens e das audiências" funcionando como uma espécie de narrador da sociedade, o que demonstra sua ancoragem no cotidiano, isto é, na vida de todos os dias, na vida de todos os homens, em que sonhos, desejos e rotinas coexistem ${ }^{6}$. Para Lopes ${ }^{7}$, falar em cultura no Brasil implica, necessária e concomitantemente, discorrer sobre a telenovela brasileira, um produto estético e cultural reconhecido pelo público e que toma centralidade na cultura e na identidade do País. Daí emerge o papel educativo da telenovela, quando traz ao público pouco informado certas discussões, como diz Baccega ${ }^{8}$.

Trazemos também para este trabalho nossa compreensão de que a telenovela representa um bem cultural-midiático, no qual práticas, representações e sentidos de consumo podem ser identificados ${ }^{9}$. O consumo, compreendido aqui como fenômeno cultural da contemporaneidade, nos evidencia como "os bens são investidos de valores socialmente utilizados para expressar categorias e princípios, cultivar ideias, fixar e sustentar estilos de vida, enfrentar mudanças ou criar permanências" $"$.

As perspectivas acima lançadas nos possibilitam dizer que comunicação e consumo, por assim dizer, estão imbricados, constituídos e constituintes, na/ da cultura. O caleidoscópio até aqui proposto também nos confere abertura

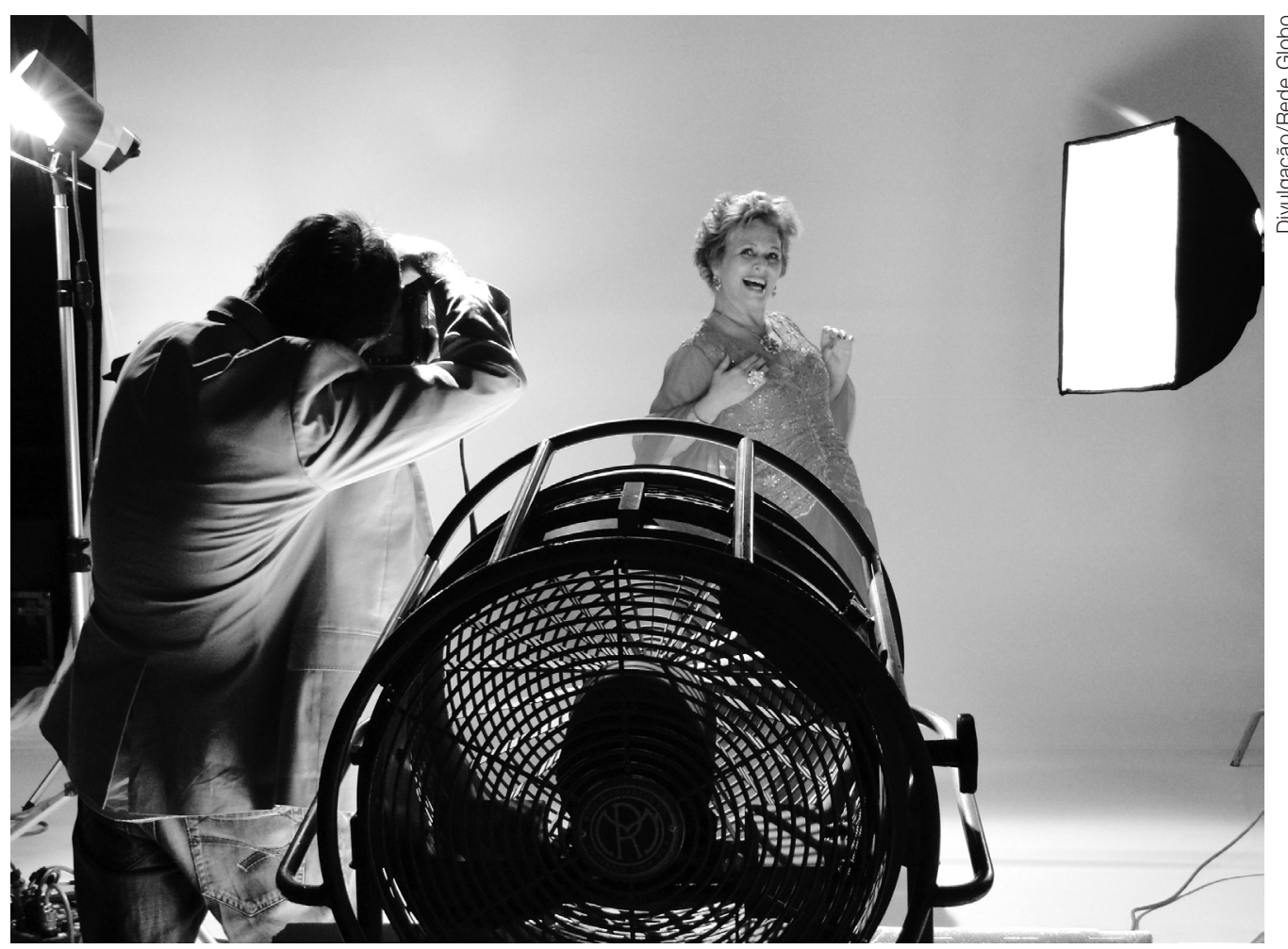

Irene Ravache interpreta Clô na telenovela Passione. 
para trazer à reflexão a telenovela Passione, focalizando nossa atenção na personagem Clotilde Iolanda Souza e Silva (Clô), que, entendemos, permite-nos mostrar o papel do consumo na atualidade como chave de leitura da sociedade contemporânea.

\section{PASSIONE E A SOCIEDADE DE CONSUMO}

A novela Passione, de Silvio de Abreu, foi exibida no período de 17 de maio de 2010 a 14 de fevereiro de 2011, às 21h, em horário nobre, pela Rede Globo. A trama, ambientada principalmente em São Paulo, procurou mostrar diversas regiões da cidade como Morumbi, Jardins, Tatuapé, Avenida Paulista e CEAGESP. Muito embora a narrativa tenha se constituído em torno de um segredo de família, protagonizado por Bete Gouveia (Fernanda Montenegro), seu marido Eugênio (Mauro Mendonça) e seu filho Totó (Tony Ramos), envolvendo ciúme, herança, interesses, assassinato e suspense, voltamos nosso olhar para o núcleo cômico da novela. Composto de Clotilde Iolanda Souza e Silva (Irene Ravache), Olavo (Francisco Cuoco), Jéssica (Gabriela Duarte), Berillo (Bruno Gagliasso), Fortunato (Flávio Migliaccio), Guida (Andrea Bassit), este núcleo representa uma família de emergentes da Zona Leste de São Paulo. De maneira lúdica estes personagens, principalmente Clotilde Iolanda Souza e Silva (Clô), para quem canalizamos nossa atenção neste trabalho, traz à cena a busca de emergentes pelo pertencimento à nova classe social e o reconhecimento de famílias ricas tradicionais, através do consumo.

Estes personagens incorporam uma das características da realidade brasileira atual, que é a migração de "famílias provenientes das classes mais baixas para as camadas com maior potencial de consumo"11. Entre 2003 e 2009, 29 milhões de brasileiros chegaram à chamada classe $\mathrm{C}$, também conhecida como nova classe média. Neste mesmo período, outros 7 milhões de pessoas passaram a integrar a alta renda do País e a expectativa é de que até 2014 as classes A e B comportem mais 11 milhões de pessoas ${ }^{12}$.

Silvio de Abreu, em entrevista ao veículo Meio E Mensagem, voltado a profissionais de publicidade e propaganda, afirma retratar a sociedade de consumo em suas narrativas: "Não somos artistas que trabalham apenas num conceito unicamente artístico. Nós trabalhamos dentro de um conceito artístico e comercial (...) Em todas as novelas que faço, o que eu retrato é a sociedade de consumo"'s.

Na novela Passione, por exemplo, o autor obteve recorde em merchandising, trazendo onze anunciantes para a novela ainda em seu início. Outra matéria traz a perspectiva do dirigente de marketing da emissora, Octavio Florisbal. Para ele, o crescimento econômico experimentado pelo País e as projeções otimistas colocam à Rede Globo a tarefa de rever sua programação para atender uma nova clientela: a emergente classe C. Munido de pesquisas internas, Florisbal revela que $80 \%$ de seu público continuam sendo formados pelas classes $\mathrm{C}, \mathrm{D}$ e E, mas as mudanças no perfil socioeconômico da população e a mobilidade
11. BONASSA, Antonio; FARIA, Paulo. ESPM, Seminário interno, 2011.

12. PADUAN, Roberta. Classes A e B: o mercado que mais cresce. Exame, Ed. 995 , ano 45, n. 12, p. 38-49, 2011.

13. EU retrato a sociedade de consumo. Meio \& Mensagem. Disponível em: <http://www. meioemensagem.com. $\mathrm{br} / \mathrm{home} / \mathrm{gente} / \mathrm{sapo}$ de_fora/20110516Silvio-de-Abreu.html>. Acesso em: 17 maio 2011. 
14. GLOBO muda programação para atender à nova classe $C$. UOL. 9 de maio de 2011. Disponível em: <http:// televisao.uol.com.br/ultimas-noticias/2011/05/09globo-muda-programacao-para-atender-a-nova-classe-c. $\mathrm{jhtm}>$. Acesso em: 10 maio 2011.

15. RONDELLI, Elizabeth. Realidade e ficção no discurso televisivo, n. 8 , p. 26-35, maio/ago. 1998.

16. PASSIONE. Capítulo online, 13 nov. 2010. Disponível em: <http:// passione.globo.com/capitulo/bete-decide-vender- parte-da-metalurgica. html\#resumo >. Acesso em: 9 jan. 2011. comunicação \& educação • Ano XVI • número 2 • jul/dez 2011

entre classes apresentam uma nova configuração: "Estes $80 \%$ das classes C, D e E têm uma vida própria, com características próprias. Nós precisamos atendê-los (...) O camarada mora no Tatuapé, mas não quer vir morar nos Jardins. Quer morar lá, quer ser reconhecido pela comunidade dele, ele tem os valores e hábitos dele"14, afirma o executivo.

Percebemos, portanto, a presença da realidade e da ficção no discurso televisivo. Como Elizabeth Rondelli diz, estamos falando de "programas confeccionados por produtores culturais aqui nascidos e criados, cuja base de reflexão e inspiração é o próprio País, seu povo, suas imagens (...) de modo a que brasileiros possam se reconhecer na tela"15.

Neste contexto brasileiro de possibilidade de ascensão social, Passione nos apresenta Clotilde Iolanda Souza e Silva (Clô). Interpretada pela atriz Irene Ravache, Clô é esposa de Olavo, um empresário de sucesso do setor de reciclagem; razão pela qual também é conhecida na narrativa como a Rainha do Lixo. Trata-se de uma personagem que, na condição de emergente, percorre a novela em busca de aceitação entre as socialites paulistanas.

A necessidade do reconhecimento, entre outras iniciativas, a leva a mudar de bairro e a decorar a casa com a ajuda de uma profissional. Contudo, seu esforço nunca parece suficiente para ser aceita no novo grupo social ${ }^{16}$. A seguir, para discutir consumo e constituição de identidade na cultura midiática, trabalharemos a personagem Clô em três atos: primeiro ato: endinheirada, e agora?, segundo ato: chá beneficente, um convite para o universo das socialities paulistanas e terceiro ato: do deslumbramento às origens.

\section{Primeiro ato: endinheirada, e agora?}

Selecionamos, a seguir, o primeiro discurso da personagem na novela, o qual mostra sua origem humilde e o indício de que a constituição de sua identidade está, desde o início, fortemente ancorada na sua representação midiática do consumo, isto é, nos exemplos de personalidades presentes na mídia, cuja conduta, para ela, caracteriza práticas, apenas pelos objetivos materiais que utilizam: vestidos, bolsas, anéis, pulseiras etc. A cena, exibida no dia 17 de maio de 2010, acontece em uma igreja, pouco antes do casamento de sua enteada (Jéssica), e o diálogo de Clô se dá com o noivo, Berilo, enquanto aguardam a chegada da noiva:

Clô: Chega, chega! Chega de fotos do noivo. Capricha quando a noiva estiver entrando. ... Só não estou vendo ninguém dos jornais que eu convidei... só do jornal do bairro. Pobreza! Escolhem sempre minha pior foto pra colocar na coluna e aí tenho que ouvir os comentários da cafonada: "Olha a cara dela, olha o papinho”. Ahhh! Me dá uma raiva! Mas sabe o que é? Pobre eu conheço muito bem. Já fui pobre, não gostei e não quero ser de novo. (...) Meu bem, meu bem, desce do altar. E finge que não está acontecendo nada. Eu li no livro da Danuza, é a melhor coisa. Faça como eu, sorria, sorria. Quero ver o sorrisão, hein? Obrigada. 
No dia 19 de maio de 2010, Clô, em conversa com seu marido, mostra-se preocupada com o título de rainha do lixo recebido de um jornal, após a cobertura do casamento de sua enteada, e como isso pode impactar no seu trânsito em lugares de compra frequentados pela alta sociedade paulistana:

Olavo: Ô que bom, minha querida, que você apareceu...

Clô: Eu posso falar com você sozinha? Amor, olha. Lê a legenda.

Olavo: A Rainha do Lixo...

Clô: Rainha do Lixo. Do lixo!

Olavo: Ah, é isso?

Clô: Você ri? Você ainda ri?

Olavo: Mas, coração, se eles me chamam de Rei do Lixo, qual o problema de chamar minha mulher de Rainha do Lixo? Qual o problema?

Clô: Rainha do Lixo! Rainha? Você acha que alguma mulher nesse mundo vai gostar de ser chamada de Rainha do Lixo? Amanhã, se eu for ao Jardins, entrar numa loja lá na Oscar Freire e uma vendedora falar assim pra outra: "Olha lá. Olha aquela que entrou é a Rainha do Lixo"; eu não sei o que que eu faço! Eu não sei, eu acho que eu mato! Se esse apelido pegar, você vai me prometer que você vai contratar o melhor advogado desse país, porque eu vou processar esse jornaleco.

Olavo: Eu gosto de você, pitchuquinha!

Mas o apelido de Rainha do Lixo não é o único aspecto a incomodar Clô. Como mostra parte do capítulo de 20 de maio, o bairro em que mora, na Zona Leste de São Paulo, a remete à pobreza, uma lembrança que deseja deixar para trás: "Clô: 'Ahhh! Se você soubesse a tristeza que me dá, quando saio da minha casa e olho esse bairro. É coisa de pobre, é feio, é furreca. Até quando o Olavo vai teimar em continuar morando aqui?"”.

No capítulo do dia 22 de maio de 2011, entra em pauta o gosto como representação do chique e do brega durante conversa entre Clô e sua amiga Jaqueline em um restaurante da praça de alimentação de um shopping:

Clô: Você não me deixa comprar nada com brilho. Que coisa chata, você! Jaqueline: Você não quer ser uma mulher fina, chique, elegante? Não pediu pra te ajudar?

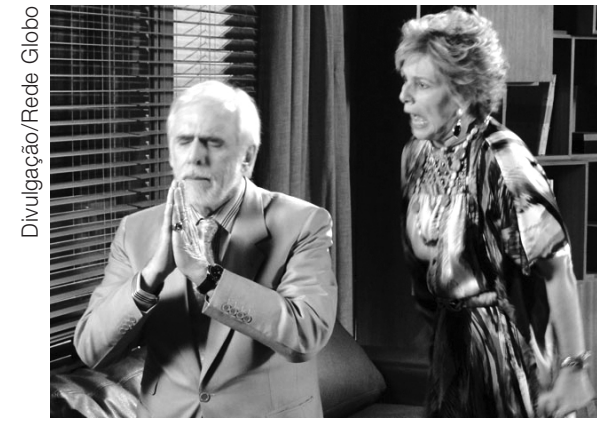

Olavo é o Rei do Lixo porque comanda a LEAR, um império de lixo reciclável que é um exemplo de aproveitamento de detritos para todo o mundo. Casado com Clô, faz de tudo para agradar a mulher.
Clô: Tudo muito sem graça Jaque! Você não me deixa comprar nada com decote... Tudo por aqui. Aquele vermelho adamascado, minha filha, eu vou voltar e eu vou comprar! Você só quer que eu use preto e cinza, preto e cinza. Praticamente uma filha de Maria! Não! Que que cê vai querer, hein?

No dia 29 de maio de 2010, o mote do capítulo é o plano de Clô, confessado para a empregada, para mudar-se da Zona Leste para o bairro Jardim América, deixando para trás o tio de seu marido, uma 
lembrança, segundo a personagem, de seus tempos de pobreza. A compra de uma mansão em um bairro nobre cresce ao longo da trama, fazendo parte das iniciativas de Clô para pertencer à alta sociedade paulistana:

Clô: Mas quando nós nos mudarmos para o Jardim América... Porque, Guida, você anota. A minha proteção é forte! Nós vamos sair deste bairro e vamos nos mudar para um lugar melhor. Eu sou o tipo da pessoa que tem força no pensamento! Eu quis deixar de ser pobre e deixei. Agora eu quero sair desse bairro e eu vou sair. Quando eu estiver lá, titio Fortunato vai estar bem longe. Porque eu não vou levar esse troféu da antiga pobreza pra ficar na minha piscina no Jardim América. Bom, você já sabe que Olavo e eu não jantamos em casa essa noite. Hoje, eu vou escolher a minha casa, no Jardim América.

Em sua festa de aniversário realizada na casa da Zona Leste de São Paulo, embora tenha convidado pessoas tidas por ela como importantes, como Constanza Pascolato, Alexandre Herchcovitch e Danuza Leão, apenas seus conhecidos de bairro compareceram, além do tio de seu marido, que a envergonhou com seu terno comprado na José Paulino, tradicional rua de comércio popular da cidade. A decepção de Clô ficou registrada na cena do dia 22 de junho de 2006:

Clô: Só a cafonada aqui do bairro. Olha o açougueiro. O açougueiro ali atrás. E aquele homem do chuchu, o japonês. Tá lá com a família lá da quitanda. Tá vendo? Tudo penetra! Porque eu não convidei. Só se foi o Olavo que convidou pra me irritar. E até agora ninguém. Ninguém que preste. Só o pipoqueiro e o amolador de facas. Ai, meu Deus! Meu Deus! Olha lá! Olha quem tá chegando! Ele não foi pra Cidade Ocean? É um espantalho! Imagina se a Danuza chega e dá de cara com isso?

Fortunato: O que foi? Eu não tô bem, não? Gastei uma nota na José Paulino! Clô: Cadê a Danuza?

Fortunato: A Danuza não veio! Quem veio sou eu. Tô aqui, ó! Não tô bonito? Não tô bonito?

Clô: Eu vou desmaiar outra vez. Eu vou... E quando eu acordar, eu vou ver esse estrupício aqui com esse paletozinho quadriculado e a gravatinha borboleta, dentro de um caixão. Eu não aguento mais essa cafonada! Saí.

No capítulo que foi ao ar no dia $1^{\circ}$ de julho de 2010, Clô experimenta roupas em lojas de um shopping com a intenção de estar exuberante para o seu primeiro jantar com a tradicional família Gouveia:

Clô: Eu tenho uma personalidade exuberante. Eu quero estar maravilhosa nesta festa! Eu vou vestir o que eu quiser.

Jaque: De repente eu fiquei imaginando você nesse jantar... No meio daquela prataria maravilhosa, dos talheres dourados, dos lustres de cristal. Daí eu pensei, pô, se tudo brilha, porque justamente minha amiga tem que ser apagada? Ah, não... Ó.

Clô: Agora sim! (...) A gente tem que mostrar pra eles que a gente tem dinheiro. Se eu for lá simplesinha, vai ser uma humilhação. 


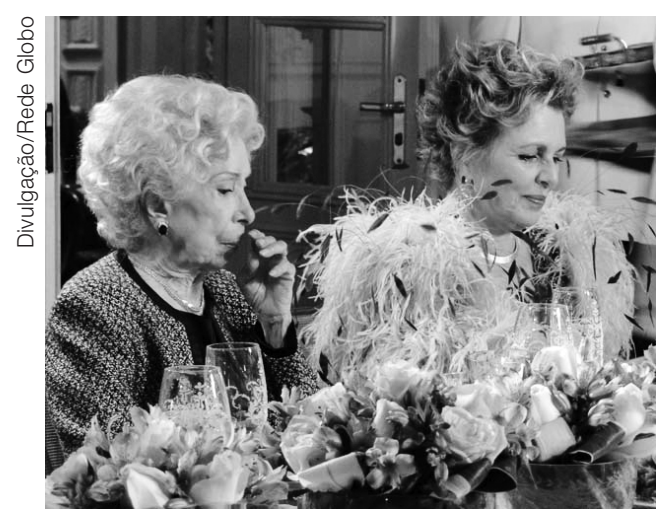

A matriarca Brígida (Cleide Yáconis) e Clô, alfinetadas da tradição contra a riqueza emergente.
Contudo, durante o jantar na mansão dos Gouveia, o choque entre o dinheiro novo e as famílias tradicionais emerge na continuidade da cena, no dia 3 de julho de 2010, no diálogo entre Clô, Brígida, uma senhora de cerca de 89 anos matriarca da família e sua neta Melina:

Clô: A senhora não imagina como Olavo e eu queremos morar aqui nesse bairro.

Brígida: Já venderam tudo; tudo que tinha por aqui! Agora só restam umas casas na Vila Madalena. Um bairro interessante... Divertido...

Melina: Imagina, vó! Tem uma linda na esquina!

Brígida: Como a senhora deve ter notado, este bairro surgiu com pessoas que nasceram aqui. E que continuam aqui, geração após geração.

Clô: Vai ser muito bom pro bairro gente jovem, é... Pessoas arrojadas, com ideias modernas... Porque senão é uma chatice, né? Fica só com a velharia, né?

Nos capítulos seguintes, Clô adquire uma mansão no Jardim América, mas entende que comprá-la não basta; é preciso decorá-la por um profissional renomado, conforme mostra a cena do dia 26 de julho de 2010:

Clô: A Françoise pediu pra ficar sozinha, porque ela quer analisar o espaço, ela precisa de inspiração... E então, é ou não é um espetáculo?

Françoise: Sua casa é realmente "marravilhosa"! Acho que vou poder fazer um bom trabalho aí...

Clô: Ai, mas que honra! Eu tinha certeza que a senhora ia aceitar... Olha! $\mathrm{Eu}$ estou com umas ideias fantásticas pra sala. Eu gosto de cor! Eu quero uma cor bem forte, vibrante. Laranja! Gosto muito de laranja! E móveis. Gosto de móveis de couro, couro de verdade, de vaca de primeira, hein? Tapetes persa, muitos tapetes!

Françoise: Um momento. Eu disse para a senhora, se eu aceitasse decorar a sua casa, seria do meu jeito.

Clô: O quê? Madame, eu vou lhe falar uma coisa, eu gosto de muito brilho, de muita cor, de muito luxo. É muito. Muito!

Françoise: Desculpe, mas, quando eu digo do meu jeito, é do meu jeito!

\section{Segundo ato: chá beneficente, um convite para o universo das socialities paulistanas}

Após mudar-se para o Jardim América, Clô entende que começa a ser aceita pela alta sociedade paulistana quando é convidada a participar de um chá beneficente organizado por Alice Carta. O Dia Rosa é uma iniciativa real, que procura estimular a prevenção do câncer de mama entre mulheres de todo o Brasil, incentivando a realização de exames, entre eles, a mamografia. $\mathrm{Na}$ 
trama, Clô, vestida de rosa, é a porta-voz deste evento na cena levada ao ar no dia 5 de novembro de 2010:

Fortunato: Que é isso? Um picolé de morango?

Clô: Um picolé? Picolé? Isso é uma roupa de grife, coisa chique!

Olavo: Você tá linda, sabe, parece uma flor!

Clô: Ai, meu amor! Olavo, hoje, finalmente, eu vou entrar para a alta sociedade paulistana! Eu fui convidada por Alice Carta para ter o meu dia rosa!

Fortunato: Rosa? Dia rosa, eu já vi tudo, viu?

Clô: Seu Fortunato, o senhor é de uma ignorância, seu Fortunato! Dia Rosa é o dia que as mulheres elegantes, as mulheres chiques, elas escolheram pra cuidar da saúde. O senhor está entendendo? É o dia em que elas vão fazer mamografia.

Olavo: Mamografia é uma chapa do seio, pra ver se tá tudo bem. Se não tem doença ruim, não é isso, meu amor?

Clô: É isso mesmo, Olavo.

Olavo: Faz muito bem, coração. Faz muito bem de cuidar da sua saúde!

Guida: Dona Clô, desculpe sabe, mas eu sou mulher também, não sou? Então, se eu quiser fazer esse exame aí da mama, eu vou ter que me vestir assim, que nem a senhora?

Clô: Não, Guida, não. Isso aqui, essa cor, é um símbolo, entendeu? Que as mulheres elegantes, as socialites, elas usam, pra quê? Pra chamar atenção. É como a minha amiga, Alice Carta, diz: "Um gesto simples, pra conscientizar as pessoas", é só isso.

Guida: Entendi.

Clô: Olavo, eu agora, oficialmente, eu sou uma socialite, meu amor! Porque o dia rosa é uma coisa, tão alta sociedade!

Olavo: Tá linda! Eu faço questão de levar você.

O Dia Rosa fez com que Clô conhecesse algumas socialities de São Paulo e, dias depois, as convidasse para um chá em sua casa. Como mostra a cena exibida no dia 13 novembro de 2010, o objetivo principal de Clô foi apresentar sua nova residência de modo a tornar-se mais próxima daquelas mulheres. Contudo, não é o suficiente, como o trecho a seguir demonstra:

Carminha: Realmente foi incrível, eu ter data livre hoje, porque minha agenda essa semana está uma loucura. E eu nem posso demorar. O desfile do Herchcovitch, você vai?

Clô: No desfile do xii... Do... Do... Atchin! Tô com uma alergia! Não vou. Não vou no desfile, porque há muitos compromissos na minha agenda também. Porque eu tenho manicure, tenho massagista. Mas eu consegui abrir uma brecha pra mostrar pra vocês conhecerem a minha casa nova. Porque eu tinha prometido isso no chá da Alice Carta, quando nos encontramos. Então, o que acham da minha nova casa, amigas?

Carminha: É... É espaçosa!

Dama 2: Eu quase comprei antes de ver a minha. Mas vazia ela tinha um certo requinte, uma elegância. Agora, gosto é bastante pessoal, é uma coisa bem pessoal mesmo. 
Clô: Ela... a minha casa foi decorada por Françoise Carron. É... Françoise Carron, não sei se vocês conhecem?

Dama 2: Sim. A romena. Ela diz que é francesa!

Clô: Romena?

Carminha: Refugiada!

Clô: É?!

Maria Eneida: Casa única no Jardim América é a da Bete Gouveia! Simples, confortável, perfeita!

Carminha: Eu adoro.

Dama 2: Berço é tudo, minhas caras!

Clô: É... Mas é um pouco tradicional demais, né?

Carminha: Da melhor tradição, querida, os Gouveia são donos de um império. A metalúrgica Gouveia é uma instituição.

Maria Eneida: Mas seu marido também é dono de um império editorial, Carminha! Vocês não ficam nada a dever aos Gouveia.

Carminha: Também não é assim. E você, Maria Eneida, não seja modesta. Se não fosse por você, seu marido jamais teria construído esse império de joalherias.

Dama 2: E você, Clotilde, o que faz o seu marido?

Clô: É Clô, o nome é Clô! Ah, o meu marido, o meu marido também é dono de um império gigantesco.

Carminha: Do quê? Bancos, construção, hotéis, tecelagem, transportes, o quê? Clô: É de... Reciclagem de resíduos.

Dama 2: Como?

Clô: Reciclagem de resíduos.

TODAS: Lixo?

Clô: Com licença, um instantinho só.

Maria Eneida: Eu acho que até o vestido é reciclado! Tá explicado!

\section{Terceiro ato: do deslumbramento às origens}

O reconhecimento de Clô só acontece perto do fim da novela, no capítulo exibido em 4 de janeiro de 2011, quando ela grava um vídeo para uma campanha sobre reciclagem para a empresa de seu marido, a Lear:

Diretor: $\mathrm{Ou}$, ou, vamos liberar o set, por favor? Vamô lá. Posição inicial, vai claquete. Take duzentos e quarenta e dois, ação.

Clô: O meio ambiente é parte fundamental de nossas vidas. É o lugar em que vivemos e precisamos preservar. Nós da Lear acreditamos na reciclagem e na importância de diminuir os efeitos que o desperdício provoca no meio ambiente. Esta embalagem, totalmente reciclável, dá a sua contribuição ao esforço em defesa do meio ambiente. Meio ambiente é vida!

Diretor: Corta. Você conseguiu! Minha musa Reciclô! Finalmente.

Olavo: Pitchuca Montenegro!

Clô: Meu amor! 
Depois da campanha Reciclô ir ao ar, os convites para participar de eventos não param de chegar, mas os compromissos começam a afastar Clô de sua família, como mostra o trecho da cena do dia 7 de janeiro de 2011:

Clô: Eu vou ao seu chá beneficente. É... Não, vai ser uma honra pra mim. Ô Guida, um momentinho, Guida, atende aí pra mim. Você gostou? Gostou da minha campanha. Muito obrigada. Você acha que eu deveria ser apresentadora de televisão? Uma nova Xuxa? Que isso? Imagina só! Não, não, não. Isso não. Bom, então, beijinho beijinho, tchau tchau! Mimoso, mimoso! Eu fui convidada pra um chá beneficente no Jóquei. Não é a Glória?

Guida: Não, Dona Clô, era um jornalista querendo falar com a senhora sobre a campanha e ligou também uma madon Mêmê convidando a senhora pra inauguração de uma loja. Olha, Dona Clô, tá tudo anotado aqui. Gente! O telefone dessa casa hoje não parou de tocar.

Clô: Ai, o meu coração parece que vai explodir! Finalmente, eu vou ser alguém. A Rainha do Lixo vai conquistar o Brasil.

Olavo: Pra mim, você sempre foi alguém. Aliás, pra mim, você sempre foi tudo. Eu estou muito orgulhoso. Eu sabia que você faria um grande sucesso com essa campanha aí. Eu larguei lá a Lear, pra almoçar com você aqui e ficarmos aqui, pertinho um do outro.

Clô: Ai, meu amor, meu amor, meu mimoso. Mas por que você não avisou que você viria? Porque eu vou ter que sair. Eu combinei com a Jaque de fazer umas compras. Quero comprar umas roupas novas.

Olavo: Mas não pode ficar pra mais tarde isso?

Clô: Não pode, não pode, não pode. Sabe por quê, meu amor? Eu não posso repetir roupa. Imagina, Olavo, se eu sair com uma roupa repetida numa revista, isso vai ser um vexame nacional. Não posso, meu amor. Paixão...

A exposição de Clô avança e seu deslumbramento também, como podemos perceber na cena veiculada no dia 7 de janeiro de 2011:

Clô: Hoje eu tenho esse vernissage, e essa semana um chá beneficente, dois jantares, inauguração de uma loja lá na Oscar Freire, uma sessão de fotos de uma revista que adorou o meu estilo e mais, oh, meu Deus, um produtor de televisão me chamou pra dar entrevista no programa... Tcharã??! ...da Ana Maria Braga!!!

Jaque: Ana Maria Braga?

Clô: Aqui, tô toda arrepiada! Desse jeito, eu vou ser convidada pra falar no Domingão do Faustão.

Jaque: Tudo isso, só por causa daquela campanha?

Clô: Não, mas é uma campanha fundamental pro meio ambiente. Lixo agora está na moda. Lixo é in. E Reciclô virou subjetivo.

Jaque: É adjetivo.

Clô: É aditivo, o que for... Ah! Eu sou um sucesso, eu sou um sucesso! Eu preciso ter uma roupa pra cada evento, entendeu, Jaque? E como eu não posso repetir, se você quiser, cê pode ficar com elas depois.

Jaque: Muito obrigada, mas os nossos gostos são muito diferentes. 


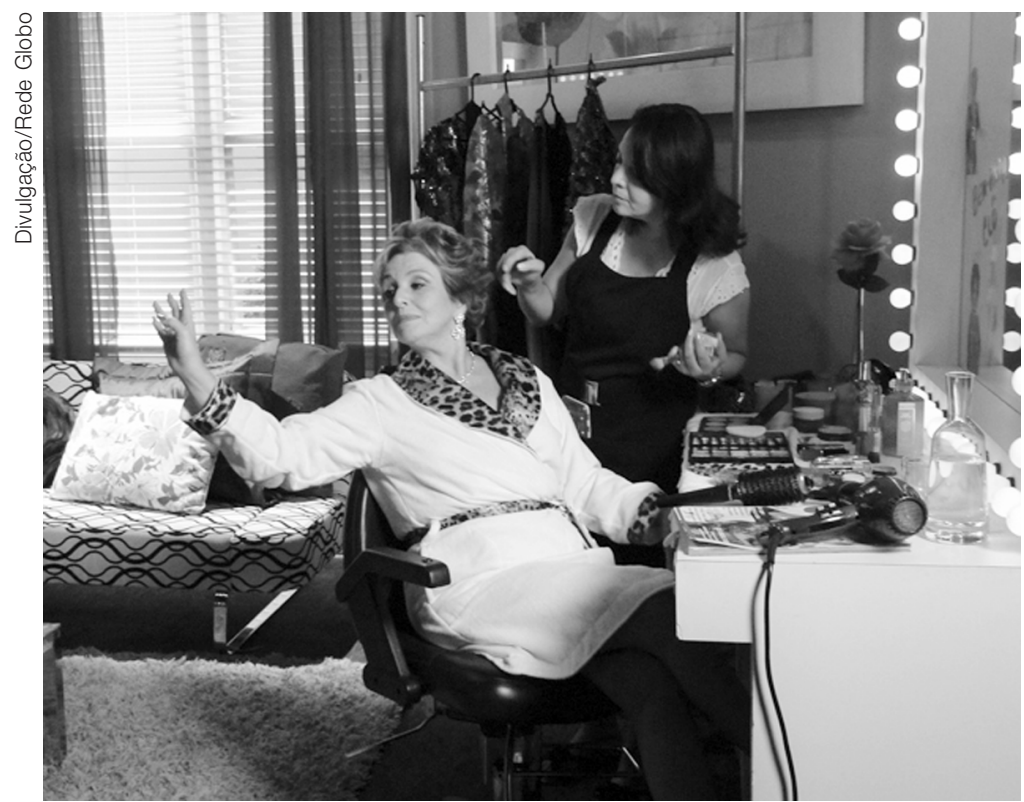

Clô, excentricidades e arrogância no camarim

Clô: Por isso que eu sou famosa e você não. Ou você acha que a campanha fez sucesso, só porque é sobre reciclagem e meio ambiente? Não. Fez sucesso devido a minha personalidade. As pessoas adoraram meu estilo, minha extravagância, meu carisma. Agora, vestida como você se veste, simplesinha, lambidinha assim, ninguém vai notar você.

Na cena do dia 11 de janeiro, Clô chega a mostrar-se arrogante e excêntrica, enquanto espera no camarim para fazer um teste na Rede Globo. Na conversa com as camareiras, Clô diz: "Esse louro ${ }^{17}$ fala demais. Eu estou no meu momento, no meu camarim, com a minha maquiadora, na minha intimidade. É minha privacidade. Champagne, muita champagne!”. Já no capítulo do dia 12 de janeiro, fala em separação com seu marido e mostra sua posição de celebridade como uma profissão:

Clô: Olavo, chega, não é?! Vamos embora, pega a sua mala. Como é que você teve coragem de me abandonar? Você deixou a sua pitchuquinha sozinha naquela mansão imensa, vazia.

Olavo: Não. Foi você que me abandonou. Você me entregou às traças, às baratas. Você me trocou pela fama.

Clô: Que isso? Fama? Eu não ligo pra fama. Eu só estou querendo exercer a minha profissão. E agora, agora eu tenho uma responsabilidade como figura pública. Eu sou uma mulher moderna, eu estou trabalhando! Você ainda não viu lá na sua fatura de cartão de crédito que eu quase não estou gastando mais o seu dinheiro?

Olavo: Vi, Vi, vi, sim. Eu preferia que você estourasse todos os limites dos cartões, mas, pelo menos, naquele tempo, você cuidava do seu mimoso.

Clô: Ah, mas então é isso? Você não aceita que eu seja uma mulher de sucesso? Você não aceita que eu tenha uma profissão?

17. Louro José, personagem do boneco ani mado que acompanha a apresentadora Ana Maria Braga no Programa Mais Você, da Rede Globo. 
18. ROCHA, Everardo. Culpa e prazer: imagens do consumo na cultura de massa. Comunicação, mídia e consumo, v. 2 n. 3, p. 136, 2005. Disponivel em: <http://www. revistas.univerciencia.org/ index.php/comunicacaomidiaeconsumo/article/ view/5088/4701>. Acesso em: jul. 2011.

19. BAUMAN, Zygmunt. Vida para o consumo: a transformação das pessoas em mercadoria. Rio de Janeiro: Jorge Zahar Ed., 2008. comunicação \& educação • Ano XVI • número 2 • jul/dez 2011

Olavo: Você chama de profissão ficar indo pra festinhas, televisão, capinha de revista?

Clô: Ai que horror! Ai que horror! Eu pensei que você fosse diferente. Eu pensei que você me amasse, que você fosse companheiro, que você vibrasse com o meu sucesso, mas eu tô vendo que não. Você é igual a todos os outros homens. Igual. Você é egoísta, Olavo. Você só pensa em você.

Olavo: E você tá pensando em quem, em mim, hein?

Clô: Mas o que é que é isso? Nós estamos no século vinte e um. Eu não sou do lar. Eu não sou das prendas domésticas. Eu agora sou uma celebridade. Você agora vai ter que aprender a conviver com isso.

No último capítulo, veiculado no dia 14 de janeiro, a personagem Clô mostra-se triste pelo distanciamento tomado de sua família e, principalmente, de seu marido, como demonstra o discurso feito pela personagem durante um evento de premiação da celebridade do ano:

Thais Araujo: E a pessoa que mais se destacou no ano que passou foi... Clô Souza e Silva.

Grazi Massafera: Clô Souza e Silva.

Jaque: Que ódio!

Clô: Muito obrigada. Muito obrigada. Eu quero agradecer. É uma honra receber esse prêmio, porque ser famosa, rica, badalada, são, são coisas maravilhosas, mas eu não posso dizer que eu esteja feliz. Porque eu consegui tudo isso, mas perdi a pessoa mais importante da minha vida. A única pessoa que, que me fez realmente feliz, que me completa. E a quem eu, eu devo tudo o que eu sou. Que é o meu Mimoso! Olavo, eu não sei se você está aí, a Jéssica prometeu que ia trazer você, mas eu, eu sei que você deve estar com muita raiva de mim... Desculpem.

Olavo: Pitchuca!

Clô: Mimoso!

Olavo: Pitchuquinha!

Clô: Mimoso!

\section{CONSIDERAÇÕES FINAIS}

A personagem Clô evidencia, concretiza o envolvimento em valores sociais de que o processo de consumo se constrói. Através dele buscamos estabelecer relações sociais, intencionalmente ou não. Nós o usamos como uma maneira de transmitir mensagens para serem lidas socialmente ${ }^{18}$, e lemos a sociedade também através delas. Para Bauman ${ }^{19}$, saímos de uma sociedade de produtores para a sociedade de consumidores, em que consumir significa uma espécie de afiliação social. Isto é, de uma sociedade concentrada na administração de corpos com o objetivo de manter boa parte de seus membros unidos no trabalho, seja no chão de fábrica ou campo de batalha, para uma sociedade em que os corpos são treinados para a individualização. Na contemporaneidade, continua Bauman, até mesmo as pessoas transformaram-se em mercadoria e 
a subjetividade, por assim dizer, traduz-se em opções de compra, opções estas partilhadas tanto pelo sujeito como por seus potenciais compradores.

Para $\mathrm{Hall}^{20}$, as identidades estão descentradas e fragmentadas na modernidade, sendo o sujeito pós-moderno capaz de assumir diferentes identidades (algumas até contraditórias) em diferentes momentos. A narrativa da personagem Clô nos mostra o seu desejo de tornar-se (mercadoria) notável, sua busca incessante pelo reconhecimento e pela fama, perante a classe social para a qual ascendeu. Numa sociedade de consumidores, como nos coloca Bauman, Clô procura tornar-se, por meio do consumo, uma mercadoria desejável e desejada. Mas ressaltamos, como alguns dos trechos de cenas aqui trazidos permitem, o fato de que Clô interpreta o consumo a partir de representações midiáticas de consumo, o que ratifica nossa colocação lançada no início deste trabalho, defendida por Baccega ${ }^{21}$, de que a mídia constitui-se em agência de socialização em busca de hegemonia na formação de sujeitos. Outro aspecto chama-nos a atenção: Clô, ao longo da trama, não incorpora plenamente os valores da alta sociedade paulistana. Este fato nos remete a Martín-Barbero ${ }^{22}$, quando este nos diz que o consumo não é, necessariamente, a interiorização de valores de outras classes. Nas classes populares, por exemplo, defende o autor e aqui endossamos, o consumo pode falar e fala de aspirações a uma vida digna. Daí concluímos este trabalho sob o fato de, na atualidade, haver a necessidade de incorporar às reflexões comunicacionais, como Rocha ${ }^{23}$ propõe, as práticas de consumo. Como Baccega ${ }^{24}$ nos afirma, na contemporaneidade, a linguagem do consumo se transformou em uma das mais poderosas formas de comunicação social.

\section{REFERÊNCIAS BIBLIOGRÁFICAS}

BACCEGA, Maria A. In: SANCHEZ, Fabio. Novela é cultura. Veja, 24 jan. 1996. . (Org.). Comunicação e culturas do consumo. São Paulo: Atlas, 2008.

- Comunicação/educação: relações com o consumo. Importância para a constituição da cidadania. Comunicação, mídia e consumo, ano 7, v. 7, n. 19, p. 49-65, 2011.

BAUMAN, Zygmunt. Vida para o consumo: a transformação das pessoas em mercadoria. Rio de Janeiro: Jorge Zahar Ed, 2008.

BONASSA, Antonio; FARIA, Paulo. Seminário interno, 2011.

FALCÃO, Maria do C. O conhecimento da vida cotidiana: base necessária à prática social. In: NETTO, José Paulo; FALCÃO, Maria do Carmo. Cotidiano: conhecimento e crítica. São Paulo: Cortez, 1989.

HALL, Stuart. A identidade cultural na pós-modernidade. 11. ed. Rio de Janeiro: DP\&A, 2006.

MARTÍN-BARBERO, J. REY, G. Os exercícios do ver: hegemonia audiovisual e ficção televisiva. São Paulo, 2004.
20. HALL, Stuart. A identidade cultural na pós-modernidade. 11. ed. Rio de Janeiro: DP\&A, 2006. 21. BACCEGA, op. cit. 2011.

22. MARTÍN-BARBERO, Jesús. Dos meios às mediações: comunicação, cultura e hegemonia. Rio de Janeiro: Editora UERJ 2009.

23. ROCHA, Rose de Melo, op. cit., 2008.

24. BACCEGA, Maria A. (Org.). Comunicação e culturas do consumo. São Paulo: Atlas, 2008. 
comunicação \& educação • Ano XVI • número 2 • jul/dez 2011

PADUAN, Roberta. Classes A e B: o mercado que mais cresce. Exame, ed. 995, ano 45, n. 12, 2011.

ROCHA, Everardo. Os bens como cultura: Mary Douglas e a antropologia (apresentação). In: DOUGLAS, Mary; ISHERWOOD. O mundo dos bens. Para uma antropologia do consumo. Rio de Janeiro: UFRJ, 2004.

ROCHA, Rose de Melo. Comunicação e consumo: por uma leitura política dos modos de consumir. In: BACCEGA, Maria A. (Org.). Comunicação e culturas do consumo. São Paulo: Atlas, 2008.

RONDELLI, Elizabeth. Realidade e ficção no discurso televisivo. Imagens. Campinas, n. 8, maio/agosto, 1998.

SILVERSTONE, Roger. Por que estudar a mídia? São Paulo: Loyola, 1999.

\section{ENDEREÇOS ELETRÔNICOS}

ANDRADE, Danubia. De conto de fadas a conto de fatos: a telenovela e suas relações com a identidade. Lumina. Revista do Programa de Pós-graduação em Comunicação da Universidade Federal de Juiz de Fora/UFJF, v. 3, n. 2, dez. 2009. Disponível em: <www.ppgcomufff.bem-vindo.net/lumina>. Acesso em: set. 2010.

EU retrato a sociedade de consumo. Meio \& Mensagem. Disponível em: $<\mathrm{http}: / /$ www.meioemensagem.com.br/home/gente/sapo_de_fora/20110516Silvio-deAbreu.html>. Acesso em: 17 maio 2011.

GLOBO muda programação para atender à nova classe C. UOL. 9 maio 2011. Disponível em: <http://televisao.uol.com.br/ultimas-noticias/2011/05/09globomuda-programacao-para-atender-a-nova-classe-c.jhtm>. Acesso em: 10 maio 2011.

LOPES, Maria I. V. de. Telenovela como recurso comunicativo. Matrizes, v. 3, n. 1, 2009. Disponível em: <http://www.matrizes.usp.br/ojs/index.php/matrizes/ article/viewFile/79/pdf_67>. Acesso em: 15 jul. 2011.

PASSIONE. Capítulo on-line, 13 nov. 2010. Disponível em: <http://passione. globo.com/capitulo/bete-decide-vender-parte-da-metalurgica.html\#resumo >. Acesso em: 9 jan. 2011.

ROCHA, Everardo. Culpa e prazer: imagens do consumo na cultura de massa. Comunicação, mídia e consumo, v. 2, n. 3, 2005. p. 136. Disponível em: <http:// www.revistas.univerciencia.org/index.php/comunicacaomidiaeconsumo/ article/view/5088/4701>. Acesso em: jul. 2011. 